\title{
Primary umbilical endometriosis: Menstruating from the umbilicus
}

\section{Primer umblikal endometriosis: Göbekten adet kanaması olması}

\section{Mustafa Taner Bostancı, Mehmet Alperen Avcı, Fatma Aksoy Khurami*, Mehmet Ali Çaparlar, Ahmet Seki}

Dıșkapı Yıldırım Beyazıd Training and Research Hospital, Clinic of General Surgery, Ankara, Turkey *Dıșkapı Yıldırım Beyazıd Training and Research Hospital, Clinic of Pathology, Ankara, Turkey

\begin{abstract}
Primary umbilical endometriosis is a rare disorder and is defined as the presence of ectopic endometrial tissue within the umbilicus. The clinical diagnosis of cutaneous endometriosis remains challenging due to the variable clinical appearance and symptoms of the condition. A 50-yearold female patient with no history of previous pelvic surgery was admitted to our outpatient clinic because of a painful nodule on her umbilical region, bleeding with her menstrual cycle. After a total excision and histopathological examination of the patient's lesion, the diagnosis of primary umbilical endometriosis was established. This case highlights the importance of including primary umbilical endometriosis in the differential diagnosis in women with a painful umbilical nodule.
\end{abstract}

Keywords: Endometriosis, primary, skin, umbilical

\section{Öz}

Primer umblikal endometriosis nadir bir hastalıktır ve göbekte ektopik endometrial dokunun varlığı olarak tanımlanır. Kutanöz endometriosisin klinik tanısı değişik klinik görünüm ve semptomlar nedeniyle zordur. Elli yaşındaki bayan hasta polikliniğimize göbek bölgesinde menstrüel dönemde kanama gösteren ağrılı bir nodül nedeniyle başvurdu. Özgeçmişinde pelvik cerrahi öyküsü olmayan hastaya lezyonun total eksizyonu ve histopatolojik incelemesi sonucunda primer umbilikal endometriosis tanısı konuldu. Bu olgu ağrilı umbilikal nodülü olan kadınlarda ayırıc tanıda umblikal endometriosisin de düşünülmesinin gerektiğini vurgulamak amacıyla sunuldu.

Anahtar Kelimeler: Endometriosis, primer, deri, umbilikal

\section{Introduction}

Endometriosis is defined by the presence of functional endometrial tissue outside the uterine cavity. It is an important cause of infertility and affects $10-15 \%$ of all women of reproductive age ${ }^{1-3}$.

Pelvic organs, especially the ovaries, the uterosacral ligaments and the pouch of Douglas are the areas in which endometriosis commonly occurs. Women with endometriosis often suffer from dysmenorrhea, menorrhagia, pelvic pain and infertility.

Extra-pelvic endometriosis has been determined in numerous organs (i.e. gastro-intestinal organ, skin, diaphragm, lung, brain and surgical scar $)^{3-6}$

Umbilical endometriosis represents $0.5 \%$ to $1 \%$ of all cases of extragenital endometriosis. It usually occurs secondary to surgical scars, but very rarely presents as primary umbilical endometriosis 7,8 .

Umbilical endometriosis manifets itself often as a domeshaped, brown nodule; typically intermittan pain and bleeding from the umbilicus during the menstrual period usually accompanies this evidence ${ }^{9}$.

We report here a rare case of primary umbilical endometriosis.

Address for Correspondence/Yazışma Adresi: Mustafa Taner Bostancı MD, Dışkapı Yıldıım Beyazıd Training and Research Hospital,

Clinic of General Surgery, Ankara, Turkey Phone: +90 5333175888 E-mail: mtanerbostanci@gmail.com ORCID-ID: orcid.org/0000-0003-0449-2340 Received/Geliș Tarihi: 10.10.2016 Accepted/Kabul Tarihi: 14.12.2016

c Copyright 2017 by Turkish Society of Dermatology and Venereology

Turkderm-Turkish Archives of Dermatology and Venereology published by Galenos Yayınevi. 


\section{Case Report}

A 50-year-old woman, gravida 2, was admitted to the outpatient clinics with an eight-month history of umbilical nodule. She stated that the nodule had slowly increased in size and had started to bleed concomitantly with the menstrual periods in the previous 6 months. Her medical history was unremarkable and she denied symptoms of pelvic endometriosis such as dysmenorrhea, abdominal pain or dyspareunia. She was not taking any oral contraceptives and had regular menstrual cycles.

On physical examination, she had a soft, painful swelling with a diameter of $2 \mathrm{~cm}$ in the umbilicus, which was irreducible by gentle digital pressure (Figure 1). Ultrasonography revealed a hypodense nodule of $0.5 \times 1.5 \mathrm{~cm}$ in the umbilicus. Neither abdominal ultrasound nor abdominopelvic computed tomography $(\mathrm{CT})$ revealed endometrial lesions. Given the absence of an endometrial lesion both on CT and ultrasound and previous abdominopelvic surgery, a diagnosis of primer umbilical endometriosis was initially discounted.

We decided to perform surgical excision and a sub-umbilical incision was made under general anaesthesia. Excision was performed with 5-mm margins and all the fat and muscle up to the peritoneum were removed (Figure 2). There was no evidence of connection to the peritoneal cavity. The tumor was cut longitudinally and the cut-surface of the tumor was observed to be whitish grey. The cut specimens were fixed in $10 \%$ buffered formalin for 3 days and embedded in paraffin.

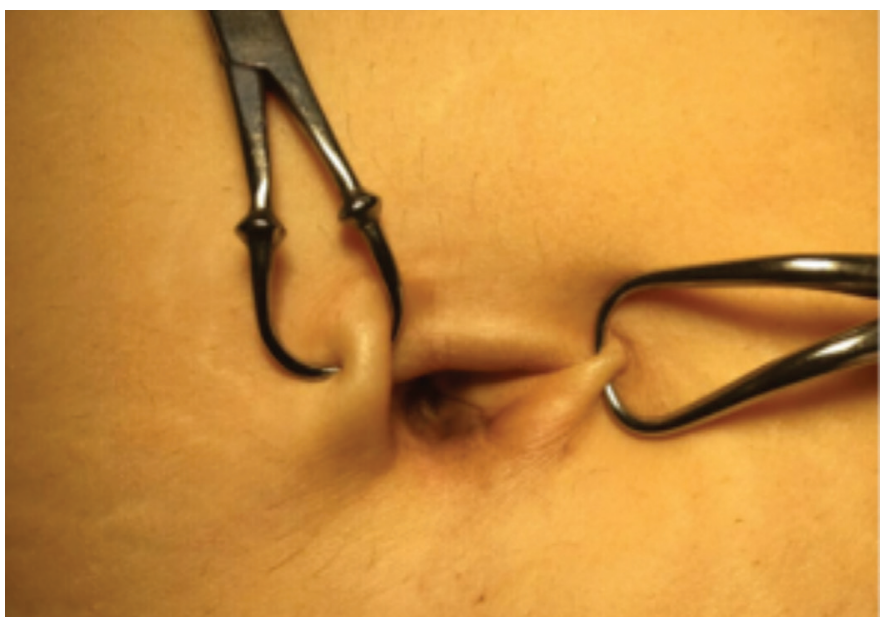

Figure 1. Umbilical endometriosis nodule

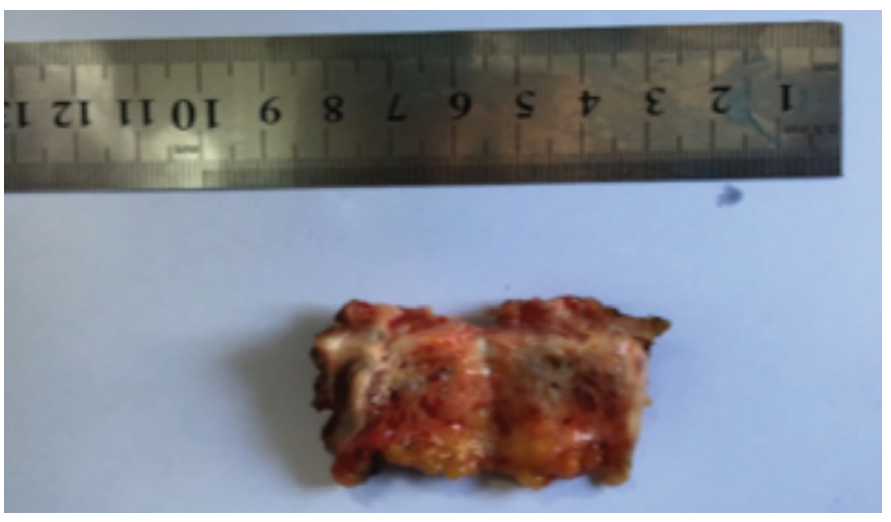

Figure 2. Excision of the nodule
Four $\mu$ m-thick sections were made and stained with hematoxylin and eosin for histopathological examination. Histology confirmed the diagnosis of endometriosis and revealed the presence of multiple foci of endometrium composed of glandular and stromal elements. No epithelial atypical cell was seen and the excision appeared complete (Figure 3). Thus, our pathological diagnosis was made as primary umbilical endometriosis.

Postoperative recovery was uneventful. The patient was informed about the risk of recurrence at the time of discharge. The patient was seen 3 months after the surgery and found to be asymptomatic with a normal umbilicus.

\section{Discussion}

Endometriosis is the presence of endometrial glands and stroma outside the uterine cavity and musculature and is a very common gynecological condition. It affects $10 \%$ to $15 \%$ of women in the reproductive age group ${ }^{1}$. Common locations of endometriosis are pelvic organs, mostly the ovaries, fallopian tubes, utero-sacral ligaments, recto-vaginal septum and pelvic peritoneum.

Extrapelvic endometriosis is a fairly uncommon disorder and difficult to diagnosis. The various sites are bladder, kidneys, ureters, bowel, omentum, liver, lungs, diaphragm, abdominal wall and extremities ${ }^{10,11}$. Cutaneous endometriosis accounts for less than $5.5 \%$ of all endometriosis cases $^{5,6}$. In the absence of a prior surgical history, endometriosis is termed spontaneous (primary) cutaneous endometriosis and it accounts for less than 5.5\% of all cutaneous endometriosis ${ }^{12}$. Primary cutaneous endometriosis is mostly seen in the umbilicus.

Umbilical endometriosis is a rare disorder, widely known among gynecologists, but possibly unfamiliar to many other specialists. It was first described by Villar in 1886; so called as "Villar's umbilical nodule"2. Umbilical endometriosis substantially occur secondary to surgical, commonly laparoscopy, scars. An umbilical endometriotic lesion without surgical history is a rare condition. Some case reports have also

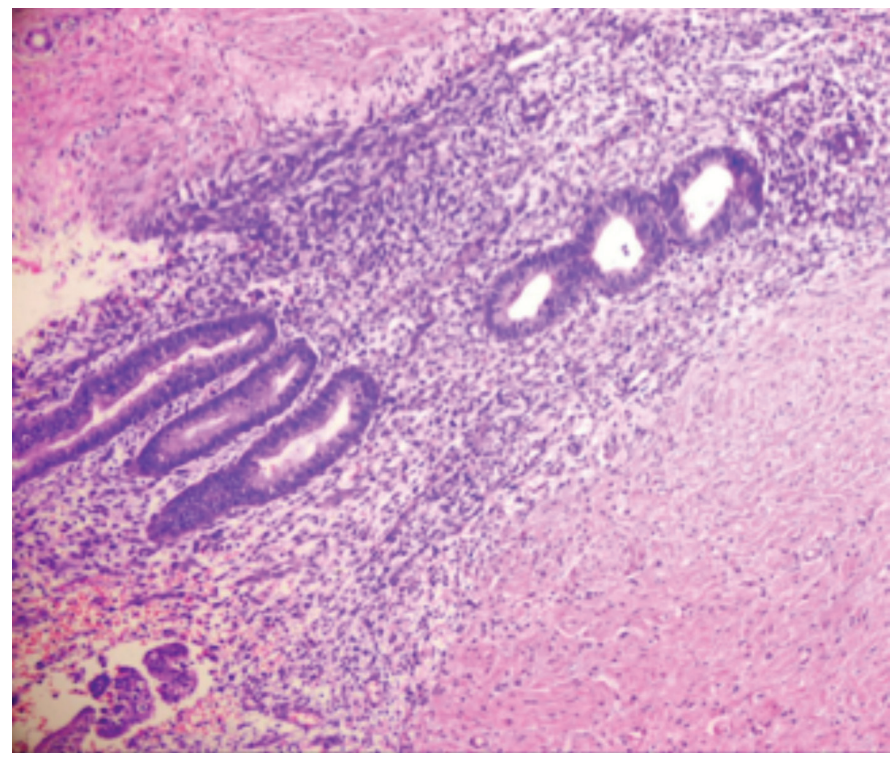

Figure 3. Histological view of the lesion demonstrated endometrial gland and stroma (hematoxylin and eosin staining: x100). 
described the presence of umbilical endometriosis during pregnancy ${ }^{13}$ The occurrence of secondary umbilical endometriosis can be explained by iatrogenic dissemination of endometrial cells during either laparoscopic or surgical procedures. However, the pathogenesis of primary endometriosis remains uncertain. Theories suggested include the implantation of cells through sanguineous or lymphatic spread, or differentiation from coelomic pluripotent cells in the skin ${ }^{5,14,15}$. $\mathrm{Bu}$ Umbilical endometriosis is commonly observed in patients of reproductive age. Its clinical manifestation consists of bluish-purple mass in the umbilicus, becoming swollen, painful and bleeding from the umbilicus during the menstrual period. They may be associated symptoms of coexistent pelvic endometriosis ${ }^{15,16}$.

The diagnosis is often clinical, based on symptoms reported by patients. Sometimes we can also use ultrasound imaging, CT scan or magnetic resonance imaging (MRI) to study the depth and the extent of the mass and if the mass is cystic or solid. However, CT scan and MRI are of little value in diagnosing intra-abdominal endometriosis ${ }^{17-19}$.

In patients operated on for umbilical endometriosis, laparoscopic exploration has been advocated in order to exclude possible further foci of intra-abdominal endometriosis, since pelvic endometriosis cannot be definitively excluded on transvaginal ultrasound or clinical examination. However, laparoscopic exploration remains debatable in asymptomatic patients ${ }^{2,4,6}$, and was not performed in our patient since she had no referred complaints typical for pelvic endometriosis.

Pyogenic granuloma, hernia, residual embryonic tissue, primary or metastatic adenocarcinoma (Sister Joseph's nodule), nodular melanoma, and cutaneous endosalpingosis must be taken into account in the differential diagnosis.

Treatment of endometriosis has not been standardized. Some authors first prescribe medical treatment such as progesterone, danazol or gonadotropin-releasing hormone analogues. While these treatments sometimes relieve symptoms such as pain and bleeding, they do not eliminate endometriosis, in particular, its cutaneous forms. It is therefore preferable to perform surgical excision with margins that are at least 5 $\mathrm{mm}$ in diameter and depth ${ }^{20,21}$.

The risk of malignant transformation from umbilical endometriosis is very low. There is a few reported cases of endometriosis with malignant transformation ${ }^{22,23}$. No treatment for a long time might lead to malignant transformation. Early surgical treatment may also result in narrow excision. Although endometriosis is a common gynaecological disease, primary umbilical endometriosis is a very rare disorder. Making a diagnosis is difficult and other causes of umbilical lesions should be considered. Primary umbilical endometriosis should be considered when examining any umbilical skin lesion in a female with no history of previous pelvic surgery, at fertile age, with cyclic symptoms like pain, swelling and bleeding associated with the menstrual and cannot be associated to pelvic endometriosis. Complete excision with successive histology is recommended for obtaining a definitive diagnosis and optimal treatment.

\section{Ethics}

Informed Consent: Consent form was filled out by all participants.

Peer-review: Externally peer-reviewed.

\section{Authorship Contributions}

Surgical and Medical Practices: M.T.B., M.A.A., F.A.K., Concept: M.T.B., A.S., Design: M.T.B., A.S., Data Collection or Processing: M.T.B., A.S.,
Analysis or Interpretation: M.T.B., A.S., Literature Search: M.A.Ç., Writing: M.T.B.

Conflict of Interest: No conflict of interest was declared by the authors.

Financial Disclosure: The authors declared that this study received no financial support.

\section{References}

1. Spaziani E, Picchio M, Di Filippo A, De Cristofano C, Ceci F, Stagnitti F: Spontaneous umbilical endometriosis: a case report with one-year followup. Clin Exp Obstet Gynecol 2009;36:263-4.

2. Fancellu A, Pinna A, Manca A, Capobianco G, Porcu A: Primary umbilical endometriosis. Case report and discussion on management options. Int $J$ Surg Case Rep 2013;4:1145-8

3. Rosina P, Pugliarello S, Colato C, Girolomoni G: Endometriosis of umbilicalcicatrix: case report and review of the literature. Acta Dermatovenerol Croat 2008;16:218-21.

4. Bagade PV, Guirguis MM: Menstruating from the umbilicus as a rare case of primary umbilical endometriosis: a case report. J Med Case Rep 2009:3:9326.

5. Victory R, Diamond MP, Johns DA: Villar's nodule: a case report and systematic literature review of endometriosis externa of the umbilicus. Minim Invasive Gynecol 2007;14:23-32

6. Kyamidis K, Lora V, Kanitakis J: Spontaneous cutaneous umbilical endometriosis: report of a new case with immunohistochemical study and literature review. Dermatol Online J 2011;17:5.

7. Latcher JW: Endometriosis of the umbilicus. Am J Obstet Gynecol 1953;66:161-8.

8. Mann LS, Clarke WR: Endometriosis of the umbilicus. IMJ III Med J 1964;125:335-6.

9. Dessy LA, Buccheri EM, Chiummariello S, Gagliardi DN, Onesti MG: Umbilical endometriosis, our experience. In vivo 2008;22:811-5.

10. Baldi A, Campioni M, Signorile PG: Endometriosis: pathogenesis, diagnosis, therapy and association with cancer. Oncol Rep 2008;19:843-6.

11. Zollner U, Girshcick G, Steck T, Dietl J. Umbilical endometriosis without previous pelvic surgery: a case report. Arch Gynecol Obstet 2003;267:258-60.

12. Fernández-Aceñero MJ, Córdova S: Cutaneous endometriosis: review of 15 cases diagnosed at a single institution. Arch Gynecol Obstet 2011;283:1041-4.

13. Razzi S, Rubegni P, Sartini A, et al: Umbilical endometriosis in pregnancy: a case report. Gynecol Endocrinol 2004;18:114-6.

14. Frischknecht F, Raio L, Fleischmann A, Dreher E, Lüscher KP, Mueller MD Umbilical endometriosis. Surg Endosc 2004;18:347.

15. Niwa K, Mizuno Y, Yano R, Ueda Y, Narikawa N, Tanaka T: Umbilical Endometriosis without Pelvic Surgery. Open Journal of Pathology 2014;4:171-5.

16. Ashraf F, Yasmin N, Islam JA, Choudhury FR, Guha K. Umbilical endometriosis in a 39 years old parous woman: A Case Report. J Shaheed Suhrawardy Med Coll 2012;4:65-7.

17. Theunissen Cl, IJpma FF. Primary umbilical endometriosis: a cause of a painful umbilical nodule. J Surg Case Rep 2015:2015

18. Rousset P, Rousset-Jablonski C, Alifano M, Mansuet-Lupo A, Buy JN, Revel MP: Thoracic endometriosis syndrome: CT and MRI features. Clin Radiol 2014;69:323-30

19. Stratton P, Winkel C, Premkumar A, et al: Diagnostic accuracy of laparoscopy, magnetic resonance imaging, and histopathologic examination for the detection of endometriosis. Fertil Steril 2003;79:1078-85.

20. Boccara $D$, Runz $A D$, Marco $O$, Chaouat $M$, Mimoun M: Primary Skin Umbilical Endometriosis: About One Case. J Clin Case Rep 2016;6:742.

21. Taniguchi F, Hirakawa E, Azuma Y, Uejima C, Ashida K, Harada T: Primary Umbilical Endometriosis: Unusual and Rare Clinical Presentation. Case Rep Obstet Gynecol 2016;2016:9302376.

22. Barbaros U, Iyibozkurt AC, Gulluoglu M, et al: Endometriotic Umbilical Port Site Metastasis after Laparoscopy. Am J Obstet Gynecol 2005;193:1761-3.

23. Obata K, Ikoma N, Oomura G, Inoue Y: Clear cell adenocarcinoma arising from umbilical endometriosis. J Obstet Gynaecol Res 2013;39:455-61. 